\title{
A CBP/p300 homolog specifies multiple differentiation pathways in C aenorhabditis elegans
}

\author{
Yang Shi ${ }^{1,3}$ and Craig Mello ${ }^{2}$ \\ ${ }^{1}$ Department of Pathology, Harvard M edical School, Boston, Massachusetts 02115 USA; ${ }^{2}$ University of Massachusetts, \\ Cancer Center, Worcester, M assachusetts 01605 USA
}

\begin{abstract}
Mammalian p300 and CBP are related transcriptional cofactors that possess histone acetyltransferase activity. Inactivation of CBP/p300 is critical for adenovinus E1A to induce oncogenic transformation and to inhibit differentiation, suggesting that these proteins are likely to play a role in cell growth and differentiation. Here we show that a C aenorhabditis elegans gene closely related to CBP/p300, referred to as cbp-1, is required during early embryogenesis to specify several major differentiation pathways. Inhibition of cbp-1 expression causes developmental arrest of $C$. el egans embryos with no evidence of body morphogenesis but with nearly twice the normal complement of embryonic cells. Mesodermal, endodermal, and hypodermal cells appear to be completely absent in most embryos, however, all of the embryos exhibit evidence of neuronal differentiation. Our analysis of this phenotype suggests a critical role for CBP-1 in promoting all non-neuronal pathways of somatic differentiation in the $C$. el egans embryo. In contrast, we show that $C$. el egans genes related to components of a conserved mammalian histone deacetylase, appear to have a role in repressing somatic differentiation. Our findings suggest a model in which CBP-1 may activate transcription and differentiation in C. elegans by directly or indirectly antagonizing a repressive effect of histone deacetylase.
\end{abstract}

[Key Words: p300; HDAC1; CBP-1; HDA-1; differentiation; C. el egans; histone acetyltransferase; histone diacetylase]

Received N ovember 11, 1997; revised version accepted December 30, 1997.

Embryonic cells are exposed to numerous intrinsic and extrinsic signals that regulate differentiation. The precise control of these differentiation signals is required both to produce specific embryonic structures and to set aside cells for later differentiation events. Although a great deal is known about the genetic pathways that control embryonic patterning and select specific developmental fates, relatively little is known about factors that are involved in differentiation decisions in general .

In Caenorhabditis elegans, early embryonic cells exhibit distinct developmental potentials as early as the two-cell stage (for a recent review, see Schnabel and Priess 1997). Several of the key developmental regulators that specify cell fates in C. elegans embryos have been identified. These include two transcriptional activators, SKN-1 and PAL-1, which are localized to the posterior bl astomere where they specify endodermal and mesodermal cell fates (Bowerman et al. 1992, 1993; Hunter and Kenyon 1996). A third posterior factor, PIE-1, specifies the germ-line fate and modulates the activities of SKN -1 and PAL-1, but appears to do so through a mechanism that involves transcriptional repression (Mello et al.

${ }^{3}$ Corresponding author.

E-MAIL yshi@warren.med.harvard.edu; FAX (617) 432-1313.
1992, 1996; Seydoux et al . 1996). A mong anterior descendants, signaling through the $\mathrm{N}$ otch-related protein GLP-1 plays a major role in distinguishing cell fates (for review, see Schnabel and Preiss 1997). In nearly al I cases, these regulators play critical roles in selecting between alternative potential fates. In the present study, we describe the analysis of several $C$. elegans genes (introduced below) that appear to have general functions in regulating differentiation. N otably, one of these $\mathrm{C}$. elegans genes, referred to here as cbp-1 for cbp, p300-related gene, and its protein product as CBP-1, appears to be essential for the function of all of the currently identified activators of cell fate in the early $C$. elegans embryo. Strikingly, blocking the expression of CBP-1 is correlated with extra cell divisions and ectopic neuronal differentiation. Blocking the expression of a second set of C. el egans genes that encode proteins related to components of a conserved mammalian histone deacetylase causes nearly opposite phenotypic effects and can bypass partially the need for the differentiation promoting functions of both CBP-1 and of the SKN-1 transcription factor.

CBP-1 is a C. elegans protein that shares significant sequence homology with mammalian p300 and CBP proteins (Chrivia et al. 1993; Arany et al . 1994; Eckner et al. 
1994; Lundblad et al. 1995), which are related transcriptional cofactors that function to integrate transcriptional and signaling events in cells (for review, see Eckner 1996; Janknecht and Hunter 1996; Goldman et al. 1997; Shikama et al. 1997). p300 was first identified in coimmunoprecipitation experiments as one of the adenovirus E1A-associated polypeptides (Yee and Branton 1985; Harlow et al. 1986), whereas CBP was first characterized as a CAM $P$ response el ement-binding protein (CREB) that potentiates the transcriptional activity of CREB (Chrivia et al. 1993; Arias et al. 1994; Kwok et al. 1994). The biological functions of p300 and CBP were first inferred from studies of the E1A oncoprotein, which can induce oncogenic transformation of primary rodent cells in cooperation with a second oncogene such as adenovirus E1B (van der Elsen et al. 1982, 1983; Ruley 1983). This growth-promoting and transforming potential of E1A is correlated, at least in part, with its ability to regulate the activity of the p300 family members (Whyte et al. 1989; Wang et al. 1995). Consistent with a role of p300 in growth regulation, overexpression of p300 suppresses E1A-induced transformation (Smits et al. 1996). More recently, p300 mutations have been identified in certain cancers (M uraoka et al. 1996), suggesting a potential connection between p300 and tumorigenesis. The ability of E1A to interfere with CBP/p300 function is also critical for E1A to inhibit differentiation (Mymryk et al. 1992; Kirshenbaum and Schneider 1995). Collectively, these observations suggest an essential role for CBP/p300 in controlling cell growth and differentiation.

Consistent with the hypothesis that CBP/p300 is important for differentiation, recent studies have shown that differentiation of myoblast cells in vitro can be inhibited by microinjection of $\alpha$-p300 antibodies (Eckner et al. 1996; Puri et al. 1997). The role of CBP/p300 in development is further supported by the finding that a Drosophila homolog is important for pattern formation during embryogenesis (Akimaru et al. 1997). CBP/p300 are targeted to promoters through interactions with multiple sequence-specific DN A-binding transcription factors (for review, see Eckner 1996; Janknecht and Hunter 1996; Goldman et al. 1997; Shikama et al. 1997). Several mechanisms have been proposed to account for the transcriptional activity of $\mathrm{CBP} / \mathrm{p} 300$, including their ability to interact with basal transcription factors (Kwok et al. 1994; Lee et al . 1996; Swope et al . 1996) or with the RN A polymerase II complex (N akajima et al . 1997a,b), or both. Recently, CBP/p300 have been shown to possess histone acetyltransferase (HAT) activity (Bannister and Kouzarides 1996; Ogryzko et al. 1996), and to associate with other HATs (X.-J. Yang et al. 1996; Chen et al. 1997). This raises an additional possibility that they may activate transcription by modifying histones and possibly other factors that are involved in transcription ( $\mathrm{Gu}$ and Roeder 1997; Imhof et al. 1997).

Hyperacetylation of histones has been correl ated with increased transcription, whereas hypoacetylation has been correlated with transcriptional repression in general (for review, see Brownell and Allis 1996; Roth 1996; Wolffe 1996; Grunstein 1997; Pazin and Kadonaga 1997;
Wade and Wolffe 1997). The level of histone acetylation is determined by the action of both HATs and histone deacetylases. The fact that $\mathrm{CBP} / \mathrm{p} 300$ possess HAT activity suggests that $\mathrm{CBP} / \mathrm{p} 300$, as transcriptional regulators, may promote transcription by overcoming a repressive function of histone deacetylases.

The first biochemically characterized histone deacetylase in mammalian cells is composed of two major components, HDACl and RbA p48 (Taunton et al . 1996; Hassig et al. 1997). HDAC1 is the mammalian homolog of the yeast RPD3 protein, which was first identified as a global transcriptional regulator that participates in both repression and activation of transcription (N asmyth et al. 1987; Vidal et al. 1990; Vidal and Gaber 1991; Stillman et al. 1994), and has also been demonstrated to be part of a histone deacetylase complex (Rundlett et al. 1996). HDAC proteins can repress transcription when targeted to the promoters, and the repression is, at least in part, dependent on the histone deacetylase activity (X.-J. Y ang et al. 1996; Alland et al. 1997; Hassig et al. 1997; Heinzel et al. 1997; Kadosh and Struhl 1997; Laherty et al. 1997; Nagy et al. 1997). On the other hand, $\mathrm{RbAp48}$ was first identified as an Rb-interacting protein (Qian et al. 1993), and since has been shown to participate in a number of protein compl exes including the histone deacetylase (Taunton et al. 1996), the chromatin assembly factor 1 (Smith and Stillman 1989; Kamakaka et al. 1996), and the chromatin remodeling N URF complexes (M artinez-Bal bas et al. 1998). The preci se function of RbAp48 in these complexes is currently unclear.

The in vivo biological functions of $\mathrm{CBP} / \mathrm{p300}$ and the underlying mechanisms through which these factors control transcription, cell growth, and differentiation are by and large undefined. We decided to turn to $C$. el egans, in which these issues can be addressed using genetic means. Our findings suggest that CBP-1 plays a central role in promoting several major differentiation events during $C$. elegans embryonic development, whereas HDAC 1- and RbA p48-rel ated proteins appear to have antagonistic, repressive functions.

\section{Results}

CBP-1 appears to promote differentiation pathways in early embryos

A search of the $C$. elegans database identified three se quences related to $\mathrm{CBP} / \mathrm{p} 300, \mathrm{R} 10 \mathrm{E} 11.1, \mathrm{~K} 03 \mathrm{H} 1.10$, and F42F12.7. The R10E11.1 locus encodes a functional protein, which we refer to here as CBP-1, that has been reported to be related to mammalian CBP and p300 (Arany et al. 1994; Lundblad et al. 1995). A multiple sequence alignment of human CBP, p300, and CBP-1 is shown in Figure 1, which illustrates the extensive sequence conservation throughout the whole protein between CBP/p300 and CBP-1. The largest block of a highly conserved region between human CBP/p300 and CBP-1 spans ami no aci ds 861-1757 of CBP-1. This regi on is encoded by a single exon (the eighth exon) of CBP-1 and contains several important functional domains de- 


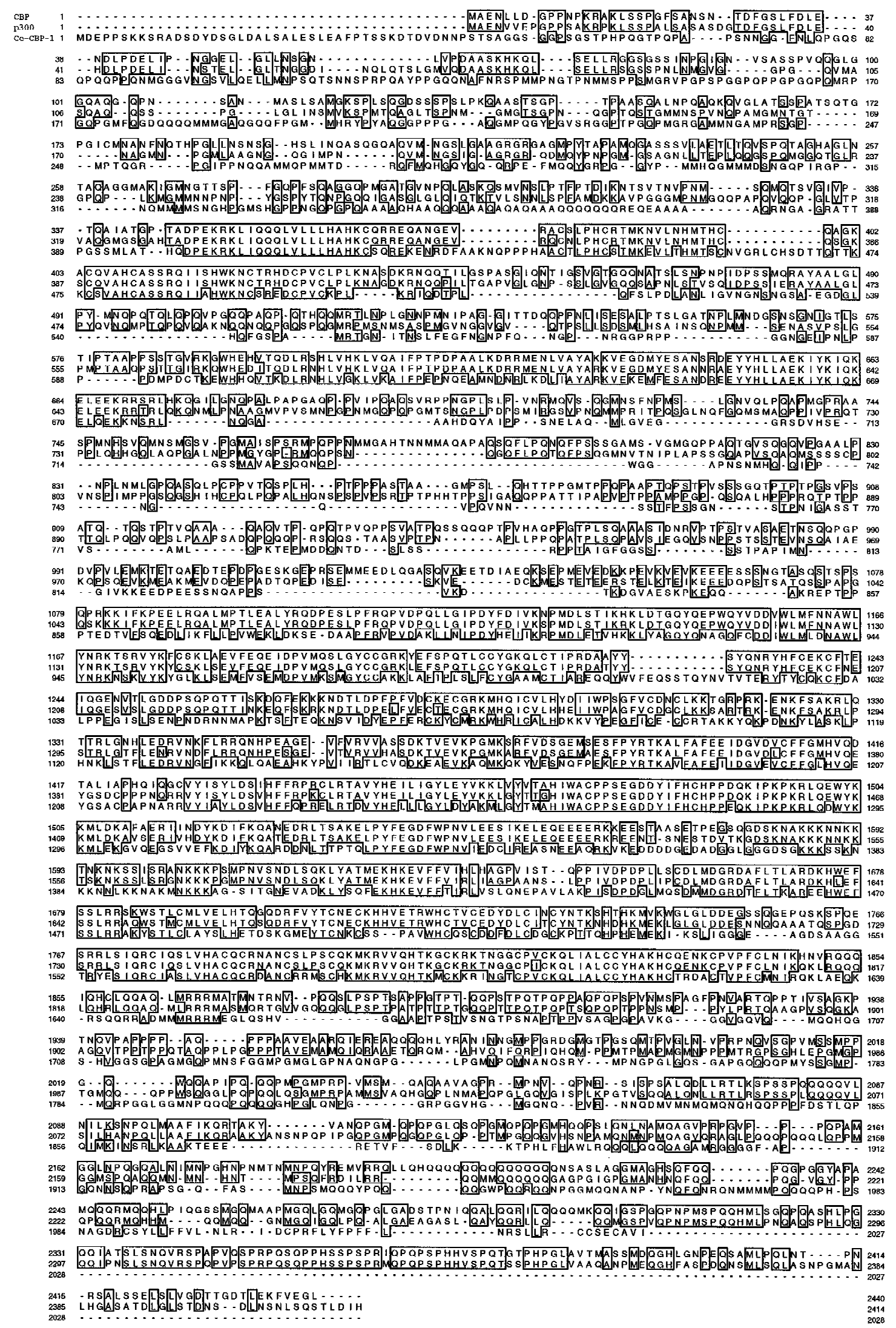

Figure 1. Sequence comparison of CBP-1 with human CBP and p300. The amino acid sequences of human CBP, p300, and C. el egans CBP-1 (R10E11.1) were aligned using the PIM A program (Human Genome Center, Baylor College of Medicine, Houston, TX). The regions of amino acid identity are boxed using the SeqVu program, Garvan Institute of M edical Research, Sydney, Australia). 
fined in CBP/p300. These include the HAT domain that possesses HAT activity (Bannister and Kouzarides 1996; Ogryzko et al. 1996), the region that is critical for binding to E1A and the HAT, P/CAF (Eckner et al. 1994; $Y$ ang et al. 1996), as well as the bromodomain and the $\mathrm{C} / \mathrm{H} 2$ domain (Eckner et al. 1994) that mediate p300 interaction with ATF-2 (Kawasaki et al. 1998). Between CBP and CBP-1, sequence comparison shows a $51 \%$ amino acid identity in the HAT domain (CBP, amino aci ds 1174-1850; CBP-1, ami no aci ds 953-1653) and 70\% in the region important for E1A and P/CAF interactions (CBP, amino acids 1801-1850; CBP-1, amino acids 15861635). The bromodomain and the $\mathrm{C} / \mathrm{H} 2$ domain (Eckner et al. 1994) show $61 \%$ and $50 \%$ amino acid identity, respectively. Another functional domain that is highly conserved is the KIX domain of CBP (amino acids 586679) that binds transcription factor CREB (Parker et al. 1996), and it shares 70\% amino acid identity with CBP-1.

In contrast, $\mathrm{KO3H} 1.10$ and $\mathrm{F} 42 \mathrm{~F} 12.7$ are two probable pseudogenes that are each associated with large direct repeats flanking a reverse transcriptase gene and are predicted to encode only truncated proteins (D. Lawson, pers. comm.). Therefore, the fact that $\mathrm{CBP} / \mathrm{p300}$ and CBP-1 share sequence homology throughout the whole protein, and the fact that all the functional domains are highly conserved, strongly suggest that CBP-1 is an evolutionarily conserved $C$. el egans homolog of mammalian $\mathrm{CBP} / \mathrm{p} 300$.

We used a reverse genetic assay, termed RN Ai (Rocheleau et al. 1997), to determine the phenotypic consequences of blocking CBP-1 expression. Several recent studies have shown that this RNA injection procedure induces phenotypes that appear identical to those that are known to result from strong or null genetic mutations in the genes tested (Guo and Kumphues 1995, 1996; Lin et al. 1995; Mello et al. 1996; Powell-Coffman et al. 1996; Guedes and Priess 1997; Rocheleau et al. 1997; Thorpe et al. 1997). Where examined, these RN Ainduced phenotypes have been correlated with a lack of protein expression from the targeted genes (Lin et al. 1995; Powell-Coffman et al. 1996). We will refer to specific experiments and to embryos thus treated with RNAi by listing the gene name followed by RNAi.

For the RNAi assay, in vitro transcribed RNA from a cbp-1 cDNA clone (yk6f6; kind gift of $\mathrm{Y}$. Kohara, National Institute of Genetics, Mishima, Japan) was injected into wild-type adult hermaphrodites. Beginning a few hours after injection, wild-type hermaphrodites that received cbp-1 RNA produced exclusively inviable embryos (see M aterials and $M$ ethods). Strikingly, the terminal cbp-1(RNAi) embryos arrest development with nearly twice the normal complement of cells, and most embryos compl etely lack evidence of muscle, intestinal, and hypodermal differentiation, as judged by their morphology in the light microscope and by immunostaining with tissue-specific antibodies (Fig. 2, cf. a with b; Table 1; data not shown). In contrast, the germ cells seem unaffected and appear normal morphologically (indicated by arrowheads in Fig. 2b) and show proper localizations of the germ-line-specific P-granules (data not shown;

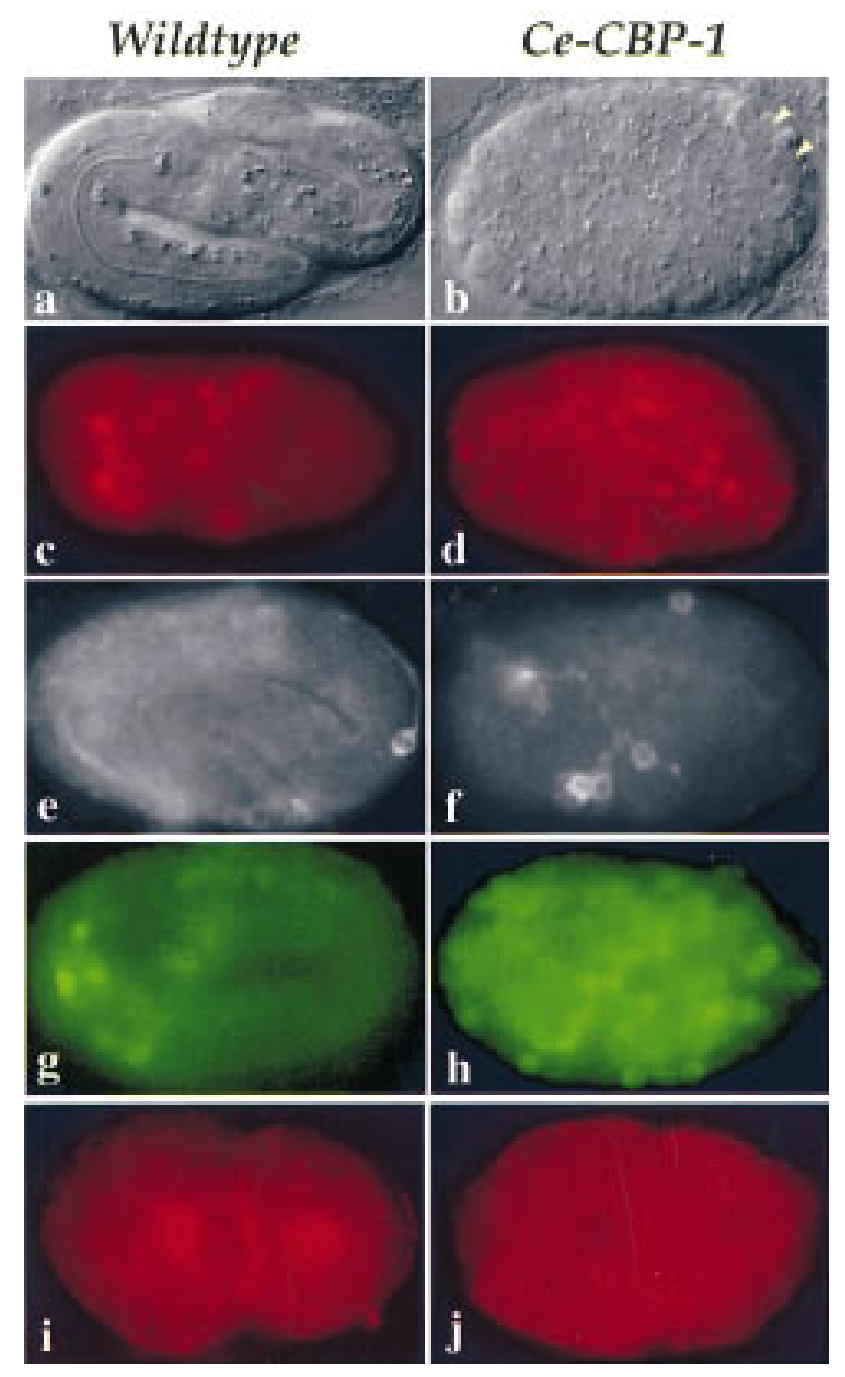

Figure 2. Expression and phenotypic analysis of CBP-1. Wildtype and cbp-1(RNAi) embryos are shown on the left and the right columns, respectively. (a,b) N omarski images $\sim 12 \mathrm{hr}$ after fertilization. The wild-type embryo in a is a threefold embryo ready to hatch. The cbp-1(RNAi) embryo in $b$ exhibits numerous small cells and shows no evidence of mesodermal, endodermal, or hypodermal tissue organization. Arrowheads indicate the two germ-line cells that appear normal morphologically. (c-h) Neuronal differentiation. Expression of UNC-86 protein (c,d); expression of MEC-7 (e,f), one of the four cells that expresses MEC-7 in wild-type embryos is shown in e; expression of HLH2::GFP (g,h). Two-cell embryos stained with affinity purified anti-human CBP antibodies, CBP $451(i, j)$. N ote that the nuclear staining is eliminated in the cbp- 1 (RNAi) embryo (j); however, apparently nonspecific cytoplasmic and membrane staining is not eliminated $(i, j)$. Under similar exposure conditions, the levels of apparent nonspecific cytoplasmic staining in both wild-type and cbp-1(RNAi) embryos are comparable.

Strome and Wood 1982). Furthermore, it appears that normal programmed cell death occurred in $100 \%$ of the cbp-1(RNAi) embryos (data not shown).

The numerous small cells produced in these embryos most closely resemble neurons, which led us to hypoth- 
Table 1. Tissue differentiation in embryos lacking Cbp-1 expression

\begin{tabular}{lcc}
\hline Tissue & $\begin{array}{c}\text { Percent } \\
\text { positive }\end{array}$ & $\begin{array}{c}\text { No. of embryos } \\
\text { scored }\end{array}$ \\
\hline Muscle & 8 & 224 \\
Intestine & 9 & 131 \\
Pharynx & 0 & 294 \\
\hline
\end{tabular}

C. el egans cbp-1(RNAi) embryos were anal yzed with antibodies recognizing proteins that are specific for muscle, gut, and pharynx tissues. Muscle tissue was scored by mAB 5.6, intestinal cells with mAb 2CB7, and pharyngeal tissue with mAb 921 (see $M$ aterials and $M$ ethods for details).

esize that many of the cells that would have differentiated into other tissues in cbp-1( + ) embryos have instead adopted neuronal fates. Consistent with this hypothesis, we found that cbp-1(RNAi) embryos contain approximately twice the normal complement of cells expressing two neuronal differentiation specific proteins, UNC-86 (Finney and Ruvkun 1990) and MEC-7 (Hamelin et al. 1992). In normal development, the UNC-86 transcription factor is expressed in 47 neuronal precursors (Finney and Ruvkun 1990; Fig. 2c). After inhibition of CBP-1 expression, $\sim 100$ cells were positively stained with $\alpha$ UN C-86 antibodies (Fig. 2d). The mec-7 gene encodes a $\beta$-tubulin specific to the touch receptor neurons, and is a marker for terminal ly differentiated neurons (Hamelin et al. 1992). U sing an $\alpha-M E C-7$ antibody (gift of G. Ruvkun, M assachusetts General Hospital, Boston, MA), we found MEC-7 expression in all four touch receptor neurons in wild-type embryos where it is detectable in both the cel I body and axonal extensions. One such cell is shown in Figure $2 \mathrm{e}$ (the other three positive cells are in different focal planes). Five to $10 \mathrm{M} \mathrm{EC}$-7-positive cel Is were found in terminal stage embryos lacking CBP-1 expression and these cells showed evidence of axon outgrowth consistent with neuronal differentiation (Fig. 2f). Finally, we found that a GFP reporter construct, HLH-2::GFP, which is expressed predominantly in neurons late in $\mathrm{C}$. el egans embryogenesis (Krause et al. 1997; Fig. 2g), is expressed in numerous cells in cbp-1(RNAi) embryos (Fig. 2h), and many of these cells exhibit what appear to be axonal extensions (data not shown). These observations suggest that CBP-1 is required for mesodermal, endodermal, and hypodermal differentiation in $C$. el egans and that extra cell divisions and neuronal differentiation may represent default developmental pathways in its absence.

CBP-1 is required for early events in mesoderm and endoderm development

To determine when in devel opment CBP-1 protein is expressed, we stained wild-type embryos with affinity-purified antibodies that recognize CBP-1 (CBP 451, Santa Cruz Biotech, CA). As shown in Figure 2i, CBP-1 protein is first detectable in nuclei beginning at the two-cell stage, and this ubiquitous nuclear staining persists at least through the 100-cell stage of embryogenesis (data not shown). This nuclear staining is completely absent in cbp-1(RNAi) embryos (Fig. 2j; data not shown), suggesting a correlation between the lack of CBP-1 expression and the phenotypes described above. The fact that CBP-1 protein is present at the two-cell stage, before the earliest detected zygotic transcription, suggests that CBP-1 is likely to be a maternally expressed protein in C. elegans.

The phenotype of cbp-1(RNAi) embryos and the observation that CBP-1 protein is present during the early cleavage stages rai se the possi bil ity that CBP-1 functions in the early embryo al ong with maternally provided cellfate determining sequence-specific DNA-binding transcription factors such as SKN -1 and PAL-1. The SKN-1 and PAL-1 proteins are localized to posterior lineages beginning at the two-cell stage where they are required to specify endodermal, mesodermal, and certain hypodermal cell fates (Bowerman et al. 1992a; Hunter and Kenyon 1996). To address the question of when in development CBP-1 activity is needed, we examined cbp1 (RNAi) embryos for early events in the differentiation of mesoderm and endoderm.

The first evidence of mesodermal-specific development is the expression of the $C$. elegans $M$ yoD homolog hlh-1 in muscle precursors in the early embryo (Krause et al . 1990), which is downstream of SKN-1 (M ello et al. 1992) and PAL-1 (Hunter and Kenyon 1996). Consistent with an early role for CBP-1 in muscle specification, we found that GFP expression driven by the Ce-M yoD promoter (kind gift of $M$. Krause) was absent in nearly all cbp-1(RNAi) embryos examined (Fig. 3, cf. a with b). The PAL-1 transcription factor activates muscle differentiation pathways in the posterior of the embryo and di rectly or indirectly activates $M$ yoD expression. In cbp-1(RNAi) embryos, maternal PAL-1 protein showed wild-type localization and normal levels of expression (data not shown). This finding, together with the fact that pal-1 and cbp-1(RNAi) embryos both show a lack of MyoD expression and muscle differentiation, suggests that CBP-1 is likely to function either along with PAL-1 (as its cofactor) or downstream of PAL-1 in the early embryonic events, leading to the activation of $M y o D$ and the specification of mesodermal precursors.

The earliest evidence for differentiation of the endoderm in $\mathrm{C}$. el egans occurs when gastrulation begins at the 28-cell stage, at which time two endodermal precursors (the E-cells) migrate into the interior of the embryo and are covered by surrounding blastomeres. The E-cells di vide again only after gastrulation is compl ete, resulting in a delay of $\sim 20 \mathrm{~min}$ in division timing in the E-lineage relative to other blastomeres in the embryo (Fig. 2c,d). This delay in division timing and the gastrulation process itself are both dependent on transcription (PowellCoffman et al . 1996) and requi re SKN-1 activity (Bowerman et al. 1992a, 1993). Consistent with an early block in endoderm differentiation in cbp-1(RNAi) embryos, we found that the E-cells showed accelerated division timing (2-min delay in the mutant vs. $26 \mathrm{~min}$ in the wildtype embryos) and failed to gastrulate in all five lineages examined (cf. Fig. 3, e and f, with the wild type shown in 
Figure 3. Early development and CBP-1 activity. Embryos from wild-type animals (top) are compared to similarly staged cbp1(RNAi) embryos (bottom). (a-b) MyoD::GFP expression in eight wild-type embryos (a), and the lack of expression in all but one cell of nine cbp-1(RNAi) embryos (b). (c-f) Early division patterns. Relevant cells are label ed and the arrows that parallel the mitotic apparatus indicate the direction of cleavage. Division of the MS sister cells, MSa and MSp, occurs with similar relative timing in wild-type (c) and cbp-1(RNAi) embryos (e). Division of E-sister cells occurs inside the embryo with a left-right orientation, 26 min after the MS division in wild-type embryos (d). In cbp-1(RNAi) embryos these cells divide on the ventral surface of the embryo, only 2 min after the MS division (f).

Fig. 2, c and d; data not shown). These observations suggest that CBP-1 acts before the 28-cell stage in $C$. el egans and may function along with SKN-1 in endoderm specification.

Identification of multiple $C$. el egans genes related to components of a conserved mammalian histone deacetylase

Both p300 and CBP are HATs, and one possible mechanism by which they activate transcription and differentiation is by modifying histones and factors involved in transcription (Bannister and Kouzarides 1996; Ogryzko et al. 1996; Gu and Roeder 1997; Imhof et al. 1997). Therefore, we wished to investi gate the genetic relationship between CBP-1 and C. el egans homologs of HDAC 1 and $\mathrm{RbAp48}$, components of a conserved mammalian histone deacetylase (T aunton et al . 1996), in differentiation.

We identified at least six $C$. el egans genes that share varying degrees of sequence similarity with HDAC1 (data not shown). Three of these genes (C53A5.3, C08B11.2, and an open reading frame in the cosmid R06C 1) share significant homology with HDAC1 and yeast RPD3 (Fig. 4), and we have named them hda-1, hda-2, and hda-3 (for HDA C 1-rel ated gene), respectively. Among them, hda-1 shares the highest sequence homology with human HDAC 1 (The GCG GAP program identifies $74 \%$ amino acid similarity and $64 \%$ amino acid identity between the two proteins). Significantly, the histidine residues located at position amino acids 150 , 151, and 188 in yeast RPD3, which have been shown to be important for the histone deacetylase acti vity (Kadosh and Struhl 1998), are conserved in all three putative C. elegans histone deacetylases (Fig. 4).

We al so identified two open reading frames, K07A 1.11 and K07A 1.12, that share extensive sequence homology with RbAp48, RbAp46, an RbAp48-related protein in mammalian cells (Qian and Lee 1995), and with p55, the RbAp48 homolog in Drosophila (Tyler et al. 1996). We refer to these two $C$. elegans genes as rba- 1 and rba-2, for RbA p48-rel ated genes. Using the GCG GAP program, we find that RBA-1 shares $53 \%$ ami no acid identity and $63 \%$ amino acid similarity with $\mathrm{RbAp} 48,52 \%$ and $63 \%$ with RbAp46, and 53\% and 62\% with Drosophila p55. RBA-2 shares $72 \%$ amino acid identity and $79 \%$ amino acid similarity with $\mathrm{RbAp} 48,71 \%$ and $80 \%$ with $\mathrm{RbAp} 46$, and $72 \%$ and $81 \%$ with Drosophila p55. A multiple sequence alignment between $\mathrm{RbA} p 48$, the Drosophila p55, RBA-1, and RBA-2 using the PIMA program is shown in Figure 5.

We examined the phenotypic consequences of inhibiting expression of HDAC1- and RbAp48-related proteins in $\mathrm{C}$. el egans using the RN Ai assay. We found that inhibiting expression of hda-1 or either of the rba genes gives rise to embryos that arrest devel opment at the onefold stage (Fig. 6a; data not shown). Although these embryos often appear to have fewer than the normal embryonic complement of 558 cells, they always exhibit evidence of tissue differentiation and proper organization of the tissue layers. The intestinal cells become polarized and express the bi refringent gut granules (Fig. 6b), muscle cells form quadrants al ong the anterior posterior body axis and undergo muscle contractions in many embryos, and the hypodermal cells spread over and surround the body of the animal (Fig. 6a; data not shown).

We also examined embryos from mothers having received simultaneous injections of RNA prepared from both rba genes. These mutant embryos arrest development with 50-100 large and often multinucleated cells. Despite this early arrest, $70 \%$ of these embryos exhibit evidence of intestinal differentiation (data not shown). These observations suggest that the two rba genes encode partially redundant functions. The underlying biologi cal cause of the embryonic arrest seen in these single and double injection experiments remains unknown at present.

We were able to obtain cross-reactive antiserum raised against the Drosophila RbA p48 homolog p55 [kind gift of J. Tyler and J. Kadonaga (Tyler et al. 1996)]. This $\alpha$-p55 antiserum detected a prominent nuclear signal present in all embryonic cells beginning at the two-cell stage (Fig. 6; data not shown). Injection of interfering RNA from either rba gene diminished but did not eliminate the $\alpha$-p55 nucl ear stai ning. However, this nucl ear staining was completely absent in the embryos obtai ned from 


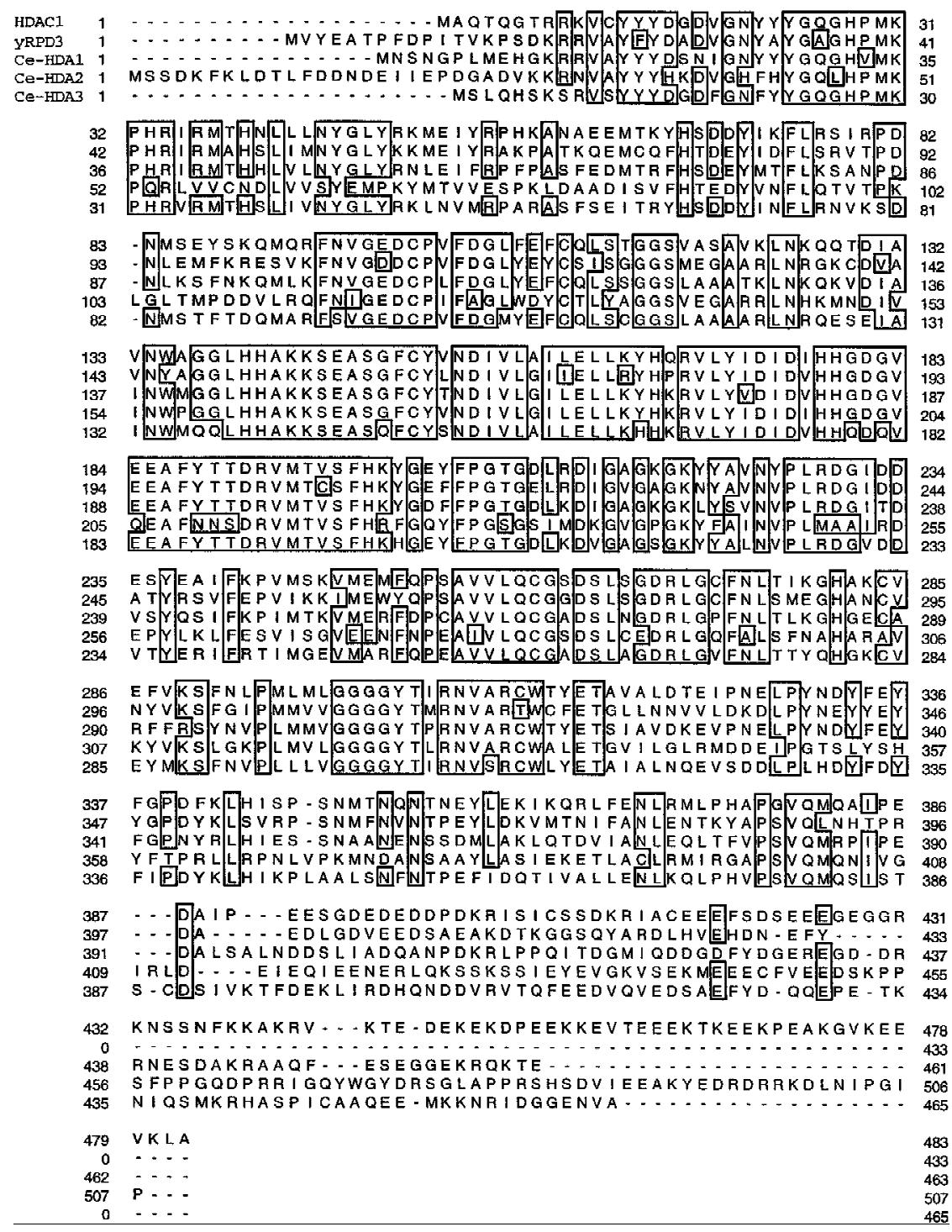

Figure 4. Identification of three $C$. el egans sequences related to mammalian HDAC1 and yeast RPD 3 . Using the BLAST program, we identified three $C$. elegans sequences from the Sanger $C$. el egans database that are closely related to human and yeast histone deacetylases represented by HDAC1 (T aunton et al. 1996) and RPD3 (Vidal and Gaber 1991), respectively. These three $C$. elegans genes are referred to here as hda-1, hda-2, and hda-3. hda-1 and hda-2 correspond to open reading frames C53A5.3 and C08B11.2, respectively. hda-3 is an open reading frame taken from the cosmid R06C 1 . The human, yeast, and C. el egans sequences were aligned using the PIM A program (Human Genome Center, Baylor College of M edicine, Houston, TX). The regions of amino acid identity are boxed using the SeqVu program, (Garvan Institute of Medical Research, Sydney, Australia). simultaneous injection of interfering RNA prepared from rba-1 and rba-2 (Fig. 6d). An unrelated early embryonic epitope recognized by the P-granule-specific antibody K76 (Strome and Wood 1982), was unaffected (Fig. $6 c, d$, FITC staining). Similarly, the expression of CBP-1 appeared unaffected (data not shown), suggesting that the interfering RN A specifically blocks expression of the targeted genes. These observations suggest that both rba-1 and rba-2 contribute to the expression of the prominent nuclear signal detected by the $\alpha$-p55 antibodies.

Interfering with expression of HDAC 1and $\mathrm{RbA}$ p48-related genes can partially suppress the differentiation defects of cbp-1(RNAi) and skn-1(zu67) mutant embryos

We first asked whether inhibiting expression of C. elegans histone deacetylaselike proteins can reverse the differentiation defects associated with the lack of CBP-1 expression. Significantly, we found that RNA interfer- ence directed against hda-1, rba-1, or rba- 2 restored endoderm differentiation in $>80 \%$ of the cbp-1(RNAi) embryos (Fig. 7a,b; data not shown), suggesting that CBP-1 may promote endoderm differentiation by directly or indirectly antagonizing the activities of histone deacetylases.

As described earlier, the endoderm differentiation defects observed in cbp-1(RNAi) embryos are similar to those caused by mutations in the transcription factor SKN-1 (Bowerman et al. 1992a; Blackwell et al. 1994). This suggests that CBP-1 may function with SKN-1 or downstream transcription factors to specify endoderm differentiation. Such a hypothesis would predict that inhibiting HDA-1 expression in the skn-1 mutant background might suppress partially the skn-1 mutant phenotype. To test this possibility, we performed hda1 (RNAi) injection experiments in homozygous skn1(zu67) mutant mothers. We find that with inhibition of hda-1 expression, endoderm differentiation is restored completel y to the resulting skn-1(zu67) mutant embryos 
Figure 5. Identification of RbAp48-related proteins in C. elegans. Using the BLAST program, we identified two $C$. elegans sequences from the Sanger $C$. el egans database that are closely related to human RbAp48 (Qian et al. 1993), RbAp46 (Qian and Lee 1995), and Drosophila p55 (Tyler et al. 1996). The two $C$. el egans genes are referred to here as rba-1 and rba-2, respectively. rba-1 and rba-2 correspond to open reading frames K07A1.11 and K07A 1.12. The sequences of human RbAp48, the Drosophila p55, rba-1, and rba-2 were aligned using the PIM A program (Human Genome Center, Baylor College of M edicine, Houston, TX). The regions of amino acid identity are boxed using the SeqVu program, (Garvan Institute of M edical Research, Sydney, Australia).

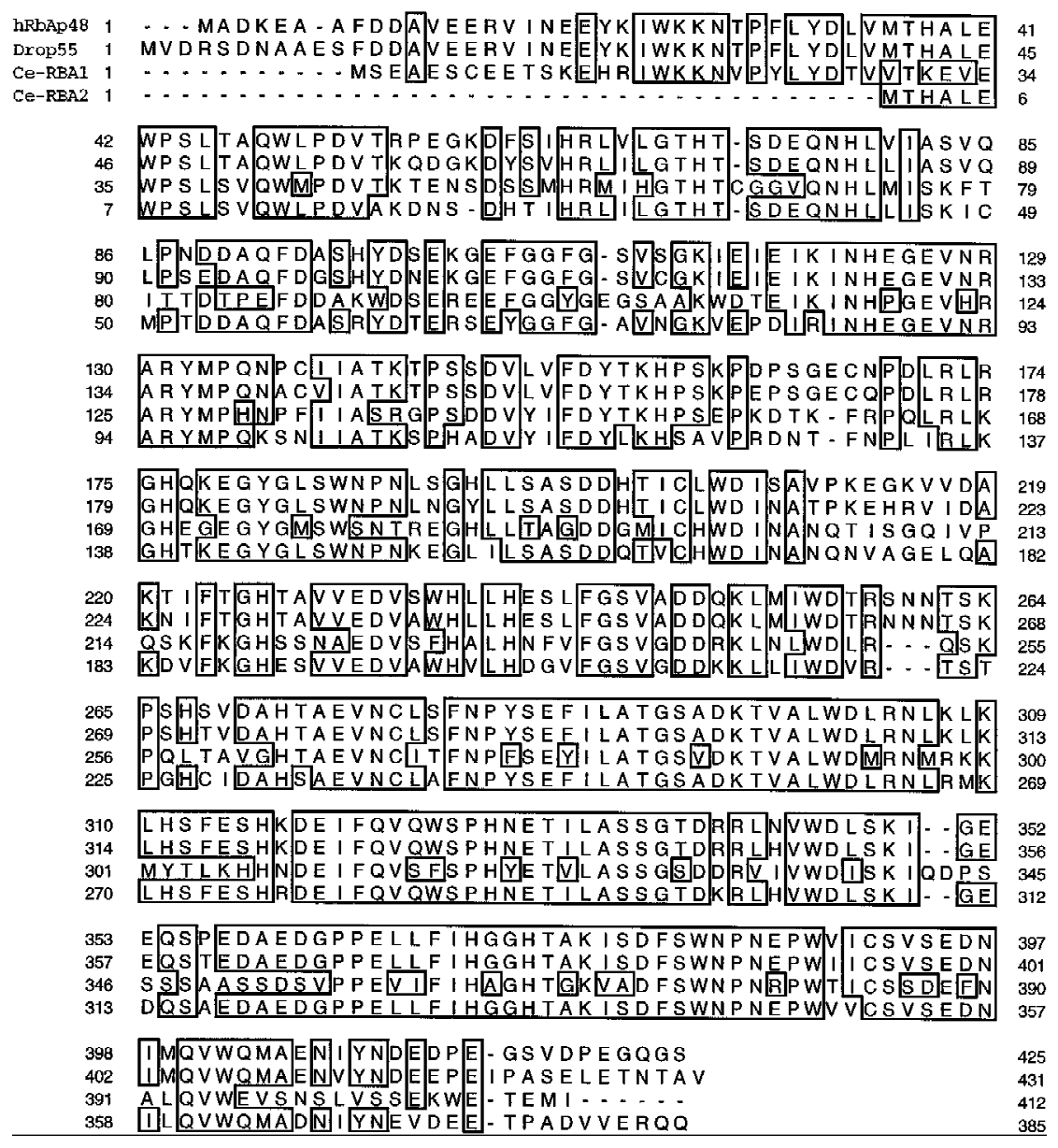

(Fig. 7c,d). Similarly, inhibiting the expression of either rba-1 or rba-2 al so restored completely endoderm differentiation in the skn-1(zu67) mutant (data not shown).

Because the skn-1(zu67) mutation is an early stop codon (C. Schubert, unpubl.) and because the expression of CBP-1 protein was not restored by inhibiting expression of HDA-1 (data not shown), the above findings suggest that blocking the expression of $\mathrm{C}$. elegans HDAC1or either of the RbAp48-related genes can bypass the need for CBP-1 and SKN-1 in the specification of endoderm. These findings suggest that the histone deacetylase related factors analyzed in this study function to regulate endoderm differentiation negatively and that SKN-1 may recruit CBP-1 to overcome this repressive effect. Although it is not clear whether this genetic relationship reflects a direct competition between these factors for acetylation and deacetylation of histones at specific promoters, nevertheless these results suggest that the ability of CBP-1 to antagonize histone deacetylase activity (directly or indirectly) is likely to be important for its differentiation-promoting functions.

\section{Discussion}

In the present study, we have shown that a gene closely related to the human p300 and CBP transcriptional cofactors functions in the early $C$. elegans embryo as a general activator necessary for the proper specification of essentially all early somatic cell fates. Remarkably, in the absence of CBP-1, many of the somatic lineages of the embryo undergo extra cell divisions and exhibit evidence of ectopic neuronal differentiation in later development. We have used the genetic context provided by these studies to examine the relationship of CBP-1 to factors rel ated to HDAC 1 and RbAp48, which are components of a conserved mammalian histone deacetylase. Our findings suggest that CBP-1 promotes endoderm differentiation by directly or indi rectly antagonizing the repressive function of histone deacetylases.

\section{A role for CBP-1 in differentiation}

Studies in vertebrate systems have shown that embryonic cells appear to adopt neuronal cell fates unless instructed to do otherwise (for review, see HemmatiBrivanlou and Melton 1997). The present study is consistent with this view and suggests that CBP-1 may represent a component that is common to nearly all nonneuronal developmental pathways in $\mathrm{C}$. el egans. Therefore, in the future, it will be interesting to determine 


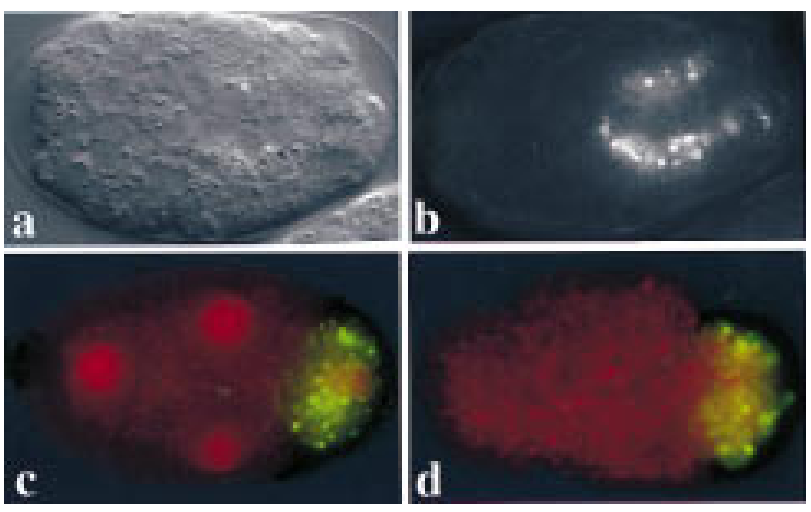

Figure 6. Histone deacetylase is essential for C. elegans embryonic development. Nomarski (a) and gut birefringence images (b) for terminal stage hda-1(RNAi) embryos showing onefold stage arrest (A very similar phenotype was observed in rba1 (RNAi) and rba-2(RNAi) embryos.) The birefringent granules visual ized in $b$ are storage products that accumulate during the terminal differentiation of gut cells. (c-d) Expression of RBA proteins in a four-cell embryos from wild-type animals before (c) and after (d) injection of a mixture of interfering RN As corresponding to rba-1 and rba-2. Embryos were stained with affinity-purified polyclonal antibodies, anti-p55, that were raised against the Drosophila RbA p48 homolog, p55, and visualized by a secondary antibody conjugated to rhodamine (red). A second antibody, K76, that recognizes the germ-line-specific P-granules was included as a control, and was visualized using an FITC conjugated secondary antibody (green). Prominent anti-p55 specific (red) nuclear staining is visible in wild type (c), but is absent after blocking both rba-1 and rba-2 expression (d). The P-granule-specific staining was not affected.

whether developmental factors that block or delay differentiation (or which promote neurogenesis) do so by blocking CBP-1 activity. It remains possible, however, that CBP-1 may be needed for a subset of neuronal differentiation pathways that we were unable to score. In addition to neurogenesis, we have observed that pathways regulating apoptosis and germ-line specification do not appear to requi re CBP-1. These observations suggest that either independent factors, or basal activities can promote these alternative cell fates in the absence of CBP-1. Alternatively, it is possible that the RN A-mediated interference assay is for some reason unable to block CBP-1 activity in some cell lineages. Therefore, the role of CBP-1 if any, in germ-line specification, apoptosis, and neurogenesis will have to await the analysis of cbp-1 null mutations .

Mechanisms that underlie the differentiationpromoting function of CBP-1

In recent studies, a correlation has been documented between the steady state of histone acetylation and the transcriptional potential of the genome; in most cases hyperacetylation is correlated with increased transcription, whereas hypoacetylation is correlated with transcriptional repression or silencing (for review, see
Brownell and Allis 1996; Roth 1996; Wolffe 1996; Grunstein 1997; Pazin and Kadonaga 1997; Wade and Wolffe 1997). The identification of nuclear HATs and histone deacetylases, and the revelation that some of these proteins are previously identified transcription factors, provide a molecular connection between HAT and transcriptional regulation. The mammalian CBP/p300 transcriptional cofactors are among the newly identified nuclear HATs. Taken together, these observations lead to a simple hypothesis that part or all of p300 activity in transcriptional activation may involve its ability to acetylate histones at the targeted promoters. A prediction of this model is that the repressive effects of histone deacetylase activities may be antagonized by CBP/p300 function in vivo.

Indeed, we have observed that a block in endoderm differentiation caused by depletion of CBP-1 can be overcome by simultaneously inhibiting the expression of the C. el egans HDAC 1 homolog HDA-1 (or the RbAp48-related proteins RBA-1 and RBA-2). Similarly, blocking the expression of HDAC1 or RbAp48-related genes can bypass the need for SKN-1 in endoderm differentiation. These genetic interactions, al ong with molecular data from other systems, are consistent with a molecular model in which the SKN -1 transcription factor may recruit CBP-1 to specific promoters to overcome differentiation repressive effects caused by a C. el egans HDAC 1/ RbAp48-like histone deacetylase complex. A future chal lenge is to determine whether the ability of CBP-1 to antagonize histone deacetylase is dependent on its inherent or associated HAT activities.

In mammalian cells, the list of sequence-specific DNA-binding transcription factors that may use CBP/ p300 as cofactors is growing steadily (for review, see Eckner 1996; Janknecht and Hunter 1996; Goldman et al. 1997; Shikama et al. 1997). Our findings suggest that
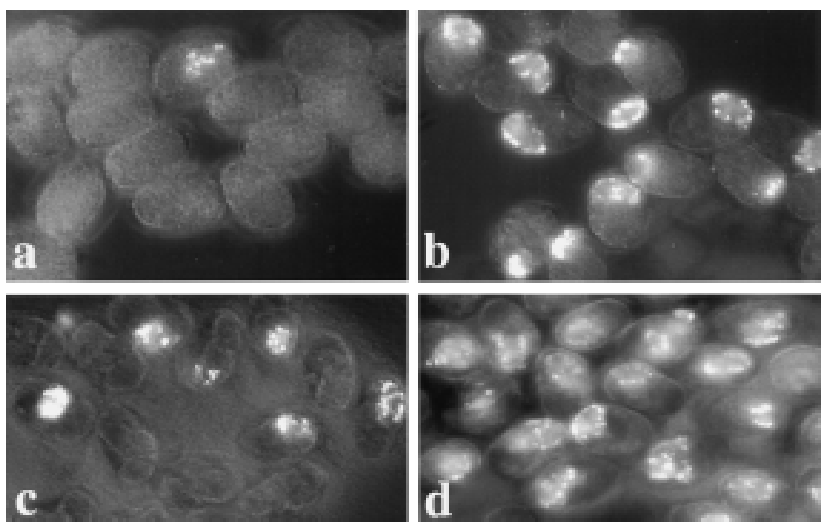

Figure 7. Rescue of endoderm differentiation by blocking the activity of histone deacetylase. (a-d) Fiel ds of terminally differentiated embryos visualized with polarized light that detects the endoderm-specific bi refringent gut granules. One of $15 \mathrm{cbp}-$ 1(RNAi) embryos is positive (a). Twelve of $14 \mathrm{cbp}$ 1(RNAi);hdal(RNAi) embryos are positive (b). Six of $15 \mathrm{em}$ bryos are positive in skn-1(zu67) mutant embryos (c). All 23 skn-1(zu67); hdal(RNAi) embryos are positive in this view (d). 
CBP-1 may exhibit similarly broad specificity in vivo during $C$. elegans embryogenesis. However, it is clear that CBP-1 is not required as a cofactor for all transcriptional events. For instance, CBP-1 is not necessary for transcription of the neuronal-specific genes such as unc86, mec-7, and hlh2 (Fig. 2), and is also not required for transcription of an early zygotic gene pes-10 (data not shown). These findings indicate that CBP-1 does not function as a promiscuous transcriptional cofactor.

In summary, our findings for the first time place a homol og of the human proteins CBP and p300 at the base of several major differentiation pathways in C. elegans. These results further suggest that CBP-1 specifies differentiation by functioning along with the early cell-fate determining transcription factors, and by antagonizing the functions of factors related to a conserved histone deacetylase complex.

\section{Materials and methods}

Strains and plasmids

The Bristol strain N 2 was used as the standard wild-type strain. HLH1::GFP, HLH2::GFP, and pes-10::GFP were kind gifts from Michael Krause (N IH/N IDDK/LMB, Bethesda, MD) and Geraldine Seydoux (Johns Hopkins School of Medicine, Baltimore, MD), respectively. cbp-1, hda-1, hda-3, rba-1, and rba-2 correspond to open reading frames R10E11.1, C53A 5.3, R06C 1 (reading frame number unassigned), K07A 1.11, and K07A 1.12, re spectively. The EST clones for cbp-1 (yk6f6), hda-1 (yk101g6), rba-1 (yk117c9), and rba-2 (yk187f5) were provided by Yuji Kohara (N IG, Japan) and hda-3 (cm18gll) by the St. Louis C. elegans Genome Project. hda-2 (corresponding to open reading frame C08B11.2) was obtained by reverse transcription coupled with PCR. Interfering RN As were synthesized in vitro using T 7 or $\mathrm{S} 6$ polymerases.

\section{Microinjection}

Microinjection experiments were performed, as described by Mello et al. (1991), by injecting RN A directly into both arms of the adult gonad. Recently, however, we have discovered that it is not necessary to inject into the gonad to induce interference among progeny of the injected mother. For several genes, the body cavity or intestinal cytoplasm appears to be a more effective target (Fire et al. 1998). With the RNAi technique, it is possible, depending on the timing of the injection and the expression properties of the gene, to observe phenotypes that correspond to distinct temporal functions of the targeted gene. For genes that function both zygotically and maternally, the first few embryos made after injection may have al ready incorporated the maternal gene product and thus "escape" the maternal RNAi defect. If a zygotic activity exists, these escapers often exhibit a phenotype that corresponds to a block in the zygotic activity of the gene (C. M ello, unpubl.). For example, in the case of glp-1, which is required zygotically for fertility, the escapers mature to form sterile adults (the zygotic phenotype for the glp-1 mutant).

In the case of cbp-1(RNAi), we observed a small window in the injected animal's brood consisting of 10 or so embryos that arrest development with morphogenesis defects but otherwise fairly normal tissue differentiation. This type of embryo occurs only in the early part of the brood after injection and is eliminated if the injections are performed into younger adults or fourth stage larvae. After this brief period, the remainder of embryos produced by the injected mother (often as many as 200-300 embryos) exhibit the stronger phenotype that we infer reflects the combination of zygotic and maternal inhibition. In principal, determining which phenotypes represent a zygotic function for cbp-1(RNAi) will have to await isolation of null mutations for the gene.

\section{Immunostaining of $C$. el egans embryos}

Antibodies against human CBP (sc-1211) were purchased from Santa Cruz Biotechnology, Inc. The $\alpha-U N C-86, \alpha-M E C-7$, and $\alpha$-p55 antibodies were kind gifts from the laboratories of $G$. Ruvkun (MGH, Boston) and J. Kadonaga (UCSD), respectively. The $\mathrm{K} 76$ antibody that recognizes the P-granule has been reported previously (Strome and Wood 1982). Embryos were permeabilized by freeze-cracking and fixed in $\mathrm{MeOH}$ for $5 \mathrm{~min}$, and rinsed in acetone for $5 \mathrm{~min}$ at $-20^{\circ} \mathrm{C}$. A ntibodies were applied directly to the air-dried samples and incubated at room temperature for $1 \mathrm{hr}$. The samples were washed in the buffer containing $100 \mathrm{~mm}$ Tris (pH 7.5) and 0.5\% Tween-20.

\section{Microscopy and lineage analysis}

Microscopy and lineage studies were performed as described (M ello et al. 1992). Light and immunofluorescence micrographs were taken electronically using a Photometrics Image Point, digital camera. The identity of differentiated cell types in experimental embryos were assigned based on morphological criteria in the light microscope, followed in most cases by analysis with differentiation-specific antibodies: muscle tissue was scored by mAB 5.6 (Miller et al. 1983), intestinal cells with 2CB7 (Bowerman et al. 1992), pharyngeal tissue with 921 or 3N B12 (Miller et al. 1983; Priess and Thomson 1987), and neurons with $\alpha-U N C-86$ and $\alpha-M E C-7$. Criteria for assigning muscle, intestinal, pharyngeal, and hypodermal cell fates were as previously described (Bowerman et al. 1992b; Mello et al. 1992).

\section{Acknowledgments}

We thank many colleagues and members of both the Shi and M ello laboratories for hel pful discussions, and Joel Rothman for sharing results before to publication. We thank Yuji Kohara for his prompt supply of many phagemids used in this study; Ji Ying Sze and Gary Ruvkun for UN C-86 and MEC-7 antibodies; Geral dine Seydoux for pes-10::GFP; M ichael Krause for HLH 1::GFP and HLH2::GFP, and for sharing unpublished results; Jessica Tyler and James Kadonaga for the $\alpha$-p55 antibodies. We also thank Dan Lawson for communicating unpublished information regarding p300-related sequences in C. elegans. Y.S. would like to extend special thanks to Scott Ogg for suggesting the RNAi experiments and help with the C. elegans database search. In addition, we would like to thank Tae Ho Shin for helpful discussions and comments on the manuscript, Dominique Calvo and Martin Victor for the sequence information of the $C$. el egans histone deacetylases and CBP-1. The research in both Shi and M ello laboratories is supported by grants from the $\mathrm{N}$ ational Institutes of Health. Y.S. and CM are recipients of the Junior faculty research award from the American Cancer Society. Additional support was provided by a M arch of Dimes Basal O'Connor award and a Pew Scholarship to C.M.

The publication costs of this article were defrayed in part by payment of page charges. This article must therefore be hereby 
marked "advertisement" in accordance with 18 USC section 1734 solely to indicate this fact.

\section{References}

Akimaru, H., Y. Chen, P. Dai, D.-X. Hou, M. Nonaka, S.M. Smolik, S. Armstrong, R.H. Goodman, and I. Shunsuke. 1997. Drosophila CBP is a co-activator of cubitus interruptus in hedgehog signalling. Nature 386: 735-738.

Alland, L., R. M uhle, H.J. Hou, J. Potes, L. Chin, N. Schreiberagus, and R.A. DePinho. 1997. Role for N-CoR and histone deacetylase in Sin3-mediated transcriptional repression. Nature 387: 49-55.

Arany, Z., W.R. Sellers, D.M. Livingston, and R. Eckner. 1994. E1A-associated p300 and CREB-associated CBP belong to a conserved family of coactivators. Cell 77: 799-800.

Arias, J., A.S. Alberts, P. Brindle, F.X. Claret, T. Smeal, M. Karin, J. Feramisco, and M. Montminy. 1994. Activation of CAMP and mitogen responsive genes relies on a common nuclear factor. Nature 370: 226-229.

Bannister, A.J. and T. Kouzarides. 1996. The CBP co-activator is a histone acetyltransferase. Nature 384: 641-643.

Blackwell, T.K., B. Bowerman, J.R. Priess, and H. Weintraub. 1994. Formation of a monomeric DNA binding domain by Skn-1 bZIP and homeodomain elements. Science 266: 621628.

Bowerman, B., B.A. Eaton, and J.R. Priess. 1992a. skn-1, a maternally expressed gene required to specify the fate of ventral blastomeres in the early C. el egans embryo. Cell 68: 10611075.

Bowerman, B., F.E. Tax, J.H. Thomas, and J.R. Priess. 1992b. Cell interactions involved in development of the bilaterally symmetrical intestinal valve cells during embryogenesis in Caenorhabditis el egans. Development 116: 1113-1122.

Bowerman, B., B.W. Draper, C.C. M ello, and J.R. Priess. 1993. The maternal gene skn-1 encodes a protein that is distributed unequally in early c. elegans embryos. Cell 74: 443452.

Brownell, J.E. and C.D. Allis. 1996. Special HATs for special occasions: linking histone acetylation to chromatin assembly and gene activation. Curr. Opin. Genet. \& Dev. 6: 176184.

Chen, H., R.J. Lin, R.L. Schiltz, D. Chakravarti, A. N ash, L. N agy, M.L. Privalsky, Y. N akatani, and R.M. Evans. 1997. $\mathrm{N}$ uclear receptor coactivator ACTR is a novel histone acetyltransferase and forms a multimeric activation complex with P/CAF and CBP/p300. Cell 90: 569-580.

Chrivia, J.C., R.P.S. Kwok, N. Lamb, M. Hagiwara, M.R. Montimy, and R.H. Goodman. 1993. Phosphorylated CREB binds specifically to the nuclear protein CBP. Nature 265: 855859.

Eckner, R. 1996. p300 and CBP as transcriptional regulators and targets of oncogenic events. Biol. Chem. 377: 685-688.

Eckner, R., M .E. Ewen, D. N ewsome, M. Gerdes, J.A. DeCaprio, J.B. Lawrence, and D.M. Livingston. 1994. M olecular cloning and functional analysis of the adenovirus E1A-associated $300-k D$ protein $(\mathrm{p} 300)$ reveals a protein with properties of a transcriptional adaptor. Genes \& Dev. 8: 869-884.

Eckner, R., T.-P. Yao, E. Oldread, and D.M. Livingston. 1996. Interaction and functional collaboration of p300/CBP and bHLH proteins in muscle and B-cell differentiation. Genes \& Dev. 10: 2478-2490.

Finney, M. and G. Ruvkun. 1990. The unc-86 gene product couples cell lineage and cell identity in C. elegans. Cell 63: 895-905.
Fire, A., S. Xu, M.K. Montgomery, S. Kostas, S.E. Driver, and C.C. M ello. 1998. Potent and specific genetic interference in C. el egans mediated by double stranded RN A. Nature 391: 806-810.

Goldman, P.S., V.K. Tran, and R.H. Goodman. 1997. The multifunctional role of the co-activator CBP in transcriptional regulation. Recent Prog. Hormone Res. 52: 103-119.

Grunstein, M. 1997. Histone acetylation in chromatin structure and transcription. Nature 389: 349-352.

Gu, W. and R.G. Roeder. 1997. Activation of p53 sequencespecific DNA binding by acetylation of the p53 C-terminal domain. Cell 90: 595-606.

Guedes, S. and J.R. Priess. 1997. The C. el egans MEX-1 protein is present in germline blastomeres and is a P granule component. Development 124: 731-739.

Guo, S. and K.J. Kumphues. 1995. par-1, a gene required for establishing polarity in C. el egans embryos, encodes a putative Ser/Thr kinase that is asymmetrically distributed. Cell 81: $611-620$.

- - 1996. A non-muscle myosin required for embryonic polarity in Caenorhabditis el egans. N ature 382: 455-458.

Hamelin, M., I.M. Scott, J.C. Way, and J.G. Culotti. 1992. The mec-7 beta-tubulin gene of Caenorhabditis elegans is expressed premarily in the touch receptor neurons. EMBO J. 11: 2885-2893.

Harlow, E., P. Whyte, B.R. Franza Jr., and C. Schely. 1986. Association of adenovirus early region $1 \mathrm{~A}$ proteins with cellular polypeptides. Mol. Cell. Biol. 6: 1579-1589.

Hassig, C.A., T.C. Fleischer, A.N . Billin, S.L. Schreiber, and D.E. Ayer. 1997. Histone deacetylase activity is required for full transcriptional repression by mSin3A. Cell 89: 341-347.

Heinzel, T., R.M . Lavinsky, T.M. Mullen, M. Soderstrom, C.D. Laherty, J. Torchia, W.M. Yang, G. Brard, S.D. N go, J.R. Davie, E. Seto, R.N. Eisenman, D.W. Rose, C.K. Glass, and M.G. Rosenfeld. 1997. A complex containing N-CoR, mSin3 and histone deacetylase mediates transcriptional repression. Nature 387: 43-48.

Hemmati-Brivanlou, A. and D. Melton. 1997. Vertebrate embryonic cells will become nerve cells unless told otherwise. Cell 88: 13-17.

Hunter, C.P. and C. Kenyon. 1996. Spatial and temporal controls target pal-1 blastomere-specification activity to a single blastomere lineage in C. el egans embryos. Cell 87: 217-226.

Imhof, A., X.-J. Yang, V.V. Ogryzko, Y. Nakatani, A.P. Wolffe, and H. Ge. 1997. A cetylation of general transcription factors by histone acetyltransferases. Curr. Biol. 7: 689-692.

Janknecht, R. and T. Hunter. 1996. Transcriptional control: Versatile molecular glue. Curr. Biol. 6: 951-954.

Kadosh, D. and K. Struhl. 1997. Repression by Ume6 involves recruitment of a complex containing Sin3 corepressor and Rpd3 histone deacetylase to target promoters. Cell 89: 365371.

- - - 1998. Histone deacetylase activity of Rpd3 is important for transcriptional repression in vivo. Genes \& Dev. (in press).

Kamakaka, R.T., P.D. Kaufman, B. Stillman, P.G. Mitsis, and J.T. Kadonaga. 1996. Postreplicative chromatin assembly by Drosophila and human chromatin assembly factor 1 . Mol. Cell. Biol. 16: 810-817.

Kawasaki, H., J. Song, R. Eckner, H. Ugai, R. Chiu, K. Raira, Y. Shi, N. Jones, and K.K. Y okoyama. 1998. p300 and ATF-2 are components of the DRF complex that regulates the retinoic acid- and E1A-mediated transcription of the c-jun gene in F9 cells. Genes \& Dev. 12: 233-245.

Kirshenbaum, L. and M.D. Schneider. 1995. Adenovirus E1A represses cardiac gene transcription and reactivates DNA 
synthesis in ventricular myocytes, via alternative pocket protein- and p300-binding domains. J. Biol. Chem. 270: 7791-7794.

Krause, M.W., A. Fire, S.W. Harrision, J. Priess, and H. Weintraub. 1990. CeM yoD accumulation defines the bodywall muscle cell fate during $C$. elegans embryogenesis. Cell 63: 907-922.

Krause, M., M. Park, J.-M. Zhang, J. Yuan, B. Harfe, S.-Q. Xu, I. Greenwald, M. Cole, B. Paterson, and A. Fire. 1997. A C. el egans $E / D$ aughterliss bHLH protein is present during neuronal but not striated muscle development. Development 124: 2179-2189.

Kwok, R.P.S., J.R. Lundblad, J.C. Chrivia, J.P. Richards, H.P. Bachinger, R.G. Brennan, S.G.E. Roberts, M.R. Green, and R.H. Goodman. 1994. N uclear protein CBP is a coactivator for the transcription factor CREB. Nature 370: 223-226.

Laherty, C.D., W.M. Yang, J.M. Sun, J.R. Davie, E. Seto, and R.N. Eisenman. 1997. Histone deacetylases associated with the mSIN 3 corepressor mediate mad transcriptional repression. Cell 89: 349-356.

Lee, J.-S., X.-L. Zhang, and Y. Shi. 1996. Differential interactions of the CREB/ATF family of transcription factors with p300 and adenovirus E1A. J. Biol. Chem. 271: 17666-17674.

Lin, R., S. Thompson, and J.R. Priess. 1995. pop-1 encodes an HMG box protein required for the specification of a mesoderm precursor in early C. el egans embryos. Cell 83: 599609.

Lundblad, J.R., R.P.S. Kwok, M.E. Laurance, M.L. Harter, and R.H. Goodman. 1995. Adenoviral ElA-associated protein p300 as a functional homologue of the transcriptional coactivator CBP. Nature 374: 85-88.

Martinez-Balbas, M.A., T. Tsukiyma, D. Gdula, and C. Wu. 1998. Drosophila N URF-55, a WD repeat protein involved in histone metabolism. Proc. Natl. Acad. Sci. 95: 132-137.

Mello, C.C., J.M. Kramer, D. Stinchcomb, and V. Ambros. 1991. Efficient gene transfer in C. elegans: Extrachromosomal maintenance and integration of transforming sequences. EMBO J. 10: 3959-3970.

M ello, C.C., C. Schubert, B. Draper, W. Zhang, B. Lobel, and J.R. Priess. 1992. The pie-1 and mex-1 genes and maternal control of blastomere identity in early $\mathrm{C}$. el egans embryos. Cell 70: 163-176.

M ello, C.C., C. Schubert, B. Draper, W. Zhang, R. Lobel, and J.R. Priess. 1996. The PIE-1 protein and germline specification in C. elegans embryos. Nature 382: 710-712.

Miller, D.M., III, I. Oritz, G.C. Berliner, and H.F. Epstein. 1983. Differential localization of two myosins within nematode thick filaments. Cell 34: 477-490.

Muraoka, M., M. Konishi, R. Kikuchi-Yanoshita, K. Tanaka, N. Shitara, J.-M. Chong, T. Iwama, and M. M iyaki. 1996. p300 gene alterations in colorectal and gastric carcinoma. Oncogene 12: 1565-1569.

Mymryk, J.S., R.W.H. Lee, and S.T. Bayley. 1992. Ability of adenovirus 5 ElA proteins to suppress differentiation of $\mathrm{BC}_{3} \mathrm{HI}$ myoblasts correl ates with their binding to a $300 \mathrm{kDa}$ cellular protein. Mol. Biol. Cell 3: 1107-1115.

N agy, L., H.Y. Kao, D. Chakravarti, R.J. Lin, C.A. Hassig, D.E. Ayer, S.L. Schreiber, and R.M. Evans. 1997. N uclear receptor repression mediated by a complex containing SMRT, mSin3A, and histone deacetylase. Cell 89: 373-380.

Nakajima, T., C. Uchida, S.F. Adderson, J.D. Parvin, and M. Montminy. 1997a. Analysis of CAM P-responsive activator reveals a two-component mechanism for transcriptional induction via signal-dependent factors. Genes \& Dev. 11: 738.

N akajima, T., C. U chida, S.F. A nderson, C.-G. Lee, J. Hurwitz, J.D. Parvin, and M. Montminy. 1997b. RNA helicase A me- diates association of CBP with RNA polymerase II. Cell 90: 1107-1112.

N asmyth, K., D. Stillman, and D. Kipling. 1987. Both positive and negative regulators of $\mathrm{HO}$ transcription are required for mother-cell-specific mating-type switch in yeast. Cell 48: $579-587$.

Ogryzko, V., R.L. Schiltz, V. Russanova, B.H. Howard, and Y. Nakatani. 1996. The transcriptional coactivator p300 and CBP are histone acetyltransferases. Cell 87: 953-959.

Parker, D., K. Ferrei, T. N akajima, V.J. LaM orte, R. Evans, S.C. Koerber, C. Hoeger, and M.R. Montiminy. 1996. Phosphorylation of CREB at Ser-133 induces complex formation with CREb-binding protein via a direct mechanism. Mol. Cell. Biol. 16: 694-703.

Pazin, M.J. and J.T. Kadonaga. 1997. What is up and down with histone deacetylation and transcription? Cell 89: 325-328.

Powell-Coffman, J.A., J. Knight, and W.B. Wood. 1996. Onset of C. el egans gastrulation is bl ocked by inhibition of embryonic transcription with an RN A polymerase antisense RNA. Dev. Biol. 178: 472-483.

Priess, J.R. and J.N. Thomson. 1987. Cellular interactions in early C. el egans embryos. Cell 48: 241-250.

Puri, P.L., M.L. Avantaggiati, C. Balsano, N. Sang, A. Graessmann, A. Giordano, and M. Levrero. 1997. p300 is required for $M$ yoD-dependent cell cycle arrest and muscle-specific gene transcription. EMBO J. 16: 369-383.

Qian, Y.-W. and E.Y.-H.P. Lee. 1995. Dual retinoblastoma-binding proteins with properties rel ated to a negative regulator of ras in yeast. J. Biol. Chem. 270: 25507-25513.

Qian, Y.-W., Y.-C.J. Wang, R.E. Hollingsworth Jr., D. Jones, N. Ling, and E.Y.-H. Lee. 1993. A retinoblastoma-binding protein related to a negative regulator of Ras in yeast. Nature 364: 648-652.

Rocheleau, C., W.D. Downs, R.L. Lin, C. Wittman, Y.X. Bei, M. Ali, J.R. Priess, and C.C. Mello. 1997. Wnt signaling and an APC related gene specify endoderm in early $C$. el egans. Cell 90: 707-716.

Roth, S.Y. 1996. Something about silencing.Nature Genetics 14: 3-4.

Ruley, H.E. 1983. Adenovirus early region $1 \mathrm{~A}$ enables viral and cellular transforming genes to transform primary cells in culture. Nature 304: 602-606.

Rundlett, S.E., A.A. Carmen, R. Kobayashi, S. Bavykin, B.M. Turner, and M. Grunstein. 1996. HDA 1 and RPD3 are members of distinct yeast histone deacetylase complexes that regulate silencing and transcription. Proc. Natl. Acad. Sci. 93: 14503-14508.

Schnabel, R. and J.R. Priess. 1997. Specification of cell fates in the early embryo. In C. el egans (ed. D.L. Riddle, T. Blumenthal, B.J. Meyer, and J.R. Preiss), pp. 361-382. Cold Spring Harbor Laboratory Press, Cold Spring Harbor, NY.

Seydoux, G., C.C. Mello, J. Pettitt, W.B. Wood, J.R. Priess, and A. Fire. 1996. Repression of gene expression in the embryonic germ lineage of $C$. el egans. Nature 382: 713-716.

Shikama, N ., J. Lyon, and N .B. Lathangue. 1997. The p300/CBP family-integrating signals with transcription factors and chromatin. Trends Cell. Biol. 7: 230-236.

Smith, S. and B.W. Stillman. 1989. Purification and characterization of CAF-1, a human cell factor required for chromatin assembly during DNA replication in vitro. Cell 58: 15-25.

Smits, P.H.M., L. de Wit, A.J. vander Eb, and A. Zantema. 1996. The adenovirus E1A-associated p300 kDa adaptor protein counteracts the inhibition of the collagenase promoter by E1A and represses transformation. O ncogene 12: 1529-1535.

Stillman, D.J., S. Dorland, and Y. Yu. 1994. Epistasis analysis of suppressor mutations that allow $\mathrm{HO}$ expression in the ab- 
sence of the yeast SW15 transcriptional activator. Genetics 136: 781-788.

Strome, S. and W.B. Wood. 1982. Immunofluorescence visualization of germ-line-specific cytoplasmic granules in embryos, Iarvae, and adults of C. el egans. Proc. Natl. Acad. Sci. 79: 15-29.

Swope, D.L., C.L. Mueller, and J.C. Chrivia. 1996. CREB-binding protein activates transcription through multiple domains. J. Biol. Chem. 271:28138-28145.

Taunton, J., C.A. Hassig, and S.L. Schreiber. 1996. A mammalian histone deacetylase related to the yeast transcriptional regulator Rpd3p. Science 272: 408-411.

Thorpe, C.J., A. Schlesinger, J.C. Carter, and B. Bowerman. 1997. Wht signaling polarizes an eaerly C. el egans blastomere to distinguish endoderm and mesoderm. Cell 90: 695705.

Tyler, J.K., M. Bulger, R.T. Kamakaka, R. Kobayashi, and J.T. Kadonaga. 1996. The p55 subunit of Drosophila chromatin assembly factor 1 is homologous to a histone deacetylaseassociated protein. Mol. Cell. Biol. 16: 6149-6159.

van der Elsen, P., S. de Parter, A. H ouweling, J. van der Veer, and A.J. van der Eb. 1982. The relationship between regions Ela and Elb of human adenoviruses in cell transformation. Gene 18: 175-185.

van der Elsen, P.J., A. Houweling, and A.J. van der Eb. 1983. M orphological transformation of human adenoviruses is determined to a large extent by gene products of region Ela. Virology 131: 242-246.

Vidal, M. and R.F. Gaber. 1991. RPD3 encodes a second factor required to achieve maximun positive and negative transcriptional states in Saccharomyces cerevisiae. Mol. Cell. Biol. 11: 6317-6327.

Vidal, M., A.M. Buckley, F. Hilger, and R.F. Gaber. 1990. Direct selection for mutants with increased K+transport in Saccharomyces cerevisiae. Genetics 125: 313-320.

Wade, P.A. and A.P. Wolffe. 1997. Histone acetyltransferases in control. Curr. Biol. 7: R82-84.

Wang, H.G., E. Moran, and P. Yaciuk. 1995. ElA promotes association between p300 and pRB in multimeric complexes required for normal biological activity. J Virol. 69: 7917-7924.

Whyte, P., N.M. Williamson, and E. Harlow. 1989. Cellular targets for transformation by the adenovirus E1A proteins. Cell 56: $67-75$.

Wolffe, A.P. 1996. Histone deacetylase: A regulator of transcription. Science 272: 371-372.

Yang, W.-M., C. Inouye, Y. Zeng, D. Bearss, and E. Seto. 1996. Transcriptional repression by $Y Y 1$ is mediated by interaction with a mammalian homolog of the yeast gl obal regulator RPD3. Proc. Natl. Acad. Sci. 93: 12845-12850.

Yang, X.-J., V.V. Ogryzko, J.-I. N ishikawa, B.H. Howard, and Y. Nakatani. 1996. A p300/CBP-associated factor that competes with the adenovirial oncoprotein E1A. Nature 382: 319-324.

Yee, S.P. and P.E. Branton. 1985. Detection of cellular proteins associated with human adenovirus type 5 early region $1 \mathrm{~A}$ polypeptides. Virology 147: 142-153. 


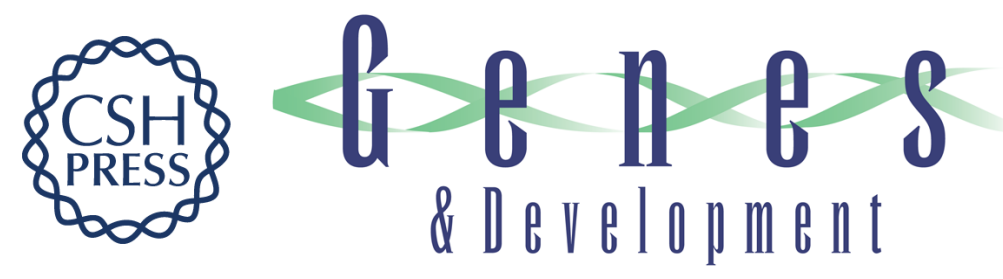

\section{A CBP/p300 homolog specifies multiple differentiation pathways in Caenorhabditis elegans}

Yang Shi and Craig Mello

Genes Dev. 1998, 12:

References This article cites 84 articles, 26 of which can be accessed free at: http://genesdev.cshlp.org/content/12/7/943.full.html\#ref-list-1

License

Email Alerting

Receive free email alerts when new articles cite this article - sign up in the box at the top Service right corner of the article or click here.

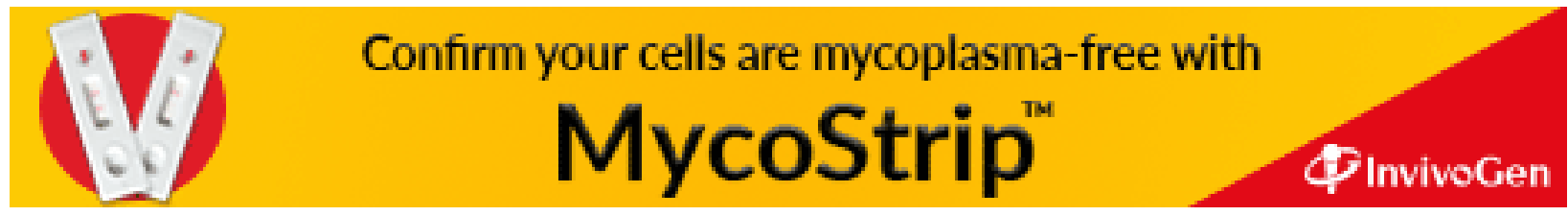

